\title{
PELAYANAN SOSIAL PADA ANAK CEREBRAL PALSY OLEH SEKOLAH LUAR BIASA
}

\author{
Oleh: \\ Franzeska Venty WD, Budhi Wibhawa, \& Budi Muhammad Taftazani \\ E-mail: \\ franzeskaven07@gmail.com
}

\begin{abstract}
ABSTRAK
Pemenuhan kebutuhan dasar merupakan tantangan besar bagi anak dengan disabilitas dalam hidupnya. Dalam pemenuhannya, anak dengan disabilitas membutuhkan pelayanan khusus yang dapat mengatasi berbagai keterbatasannya. Begitu pula dengan anak cerebral palsy, yang memiliki keterbatasan pada pengendalian fungsi pergerakkan akibat adanya kerusakan pada fungsi otak dan sistem saraf. Sekolah Luar Biasa yang menyelenggarakan pelayanan sosial, sebagai salah satu usaha kesejahteraan sosial, untuk diberikan pada anak cerebral palsy dalam bentuk kegiatan pertolongan agar mereka mampu mengatasi permasalahannya. Penelitian ini menggunakan metode kualitatif dengan pendekatan deskriptif studi kasus, agar dalam penelitian ini dapat diperoleh gambaran secara empirik tentang program pelayanan sosial apa saja yang diberikan pada anak cerebral palsy oleh Sekolah Luar Biasa, sehingga hasil penelitian ini dapat mencapai tujuan untuk menggambarkan efektivitas dari program pelayanan sosial yang diberikan. Hasil penelitian menunjukkan bahwa terdapat tiga program pelayanan sosial, yaitu pendidikan, rehabilitasi, dan keterampilan. Program pendidikan belum efektif, karena keterbatasan sumber daya guru dalam mengajari anak cerebral palsy. Program rehabilitasi sudah efektif, karena terdapat terapis yang professional dalam bidangnya memberikan layanan terapi untuk fungsi gerak anak cerebal palsy. Program keterampilan sudah efektif, karena guru dibantu pengasuh dapat mengajarkan anak untuk beraktivitas dalam hal-hal sederhana yang membantu mereka untuk hidup terampil dan mandiri.
\end{abstract}

Kata kunci: anak cerebral palsy, program pelayanan sosial, Sekolah Luar Biasa, efektivitas

\begin{abstract}
Fulfillment of basic needs is a major challenge for children with disabilities in his life. In fulfillment, children with disabilities require special services that can overcome various limitations. Similarly, the child cerebral palsy, which has limitations in controlling movement function due to damage to the brain and nervous system function. Schools that organizes social services, as one of the social welfare, to be given to children in the form of cerebral palsy relief activities so that they are able to resolve the problem. This study used a qualitative method with descriptive case study approach, so in this study can be obtained by empirical picture about any social service program given to children cerebral palsy by Extraordinary School, so the results of this research can achieve the purpose to illustrate the effectiveness of the program service social given. The results showed that there are three social service programs, namely education, rehabilitation, and skills. Education programs have not
\end{abstract}


been effective, because of limited resources teachers in teaching children cerebral palsy. Rehabilitation programs have been effective, because there are professional therapists provide services in the field of therapy for motor function of cerebral palsey children. Skills programs have been effective, because the teacher can help caregivers teach children to move in simple things that help them to live a skilled and independent.

Key words: children with cerebral palsy, social service program, school extraordinary, efectiveness

\section{PENDAHULUAN}

Dalam menjalani kehidupan, manusia senantiasa berusaha untuk mampu memenuhi kebutuhan sebagai upaya dalam meningkatkan kualitas hidupnya dan pengembangan diri seutuhnya, sehingga dapat menciptakan hidup yang sejahtera. Pada kondisi yang berbeda menjadi suatu tantangan yang besar pula bagi penyandang disabilitas, khususnya anak dengan disabilitas, untuk dapat memenuhi kebutuhan guna mencapai hidup yang lebih baik. Menurut Peraturan Menteri Sosial RI tentang Pedoman Pendataan dan Pengelolaan Data PMKS dan Potensi dan Sumber Kesejahteraan Sosial (PSKS), anak dengan disabilitas adalah penduduk berumur 0-17 tahun (berusia 17 tahun ke bawah) yang mempunyai kelainan fisik atau mental yang dapat mengganggu atau merupakan rintangan dan hambatan bagi dirinya untuk melakukan fungsi-fungsi jasmani, rohani, maupun sosialnya secara layak. Dalam memenuhi kebutuhan hidupnya, anak dengan disabilitas menghadapi berbagai keterbatasan pada dirinya untuk dapat berkomunikasi, mengurus hidup secara mandiri dan terampil, mengontrol diri, mengembangkan potensi, serta melakukan aktivitas lain dalam kesehariannya. Berdasarkan Susenas Badan Pusat Statistik RI tahun 2012 lalu, tercatat sebanyak 53.213.000 anak yang menyandang disabilitas atau sekitar 0,63 persen dari jumlah seluruh anak.

Ada pun presentase yang diperoleh dari Susenas BPS RI tahun 2012 yang melampirkan presentase anak dengan disabilitas menurut jenis gangguan atau disabilitasnya sebagai berikut:
Tabel 1.1. Presentase Anak dengan

Disabilitas Menurut Jenis Disabilitas

\begin{tabular}{|l|r|}
\hline \multicolumn{1}{|c|}{ Jenis Disabilitas } & Jumlah (\%) \\
\hline Lebih dari Satu Jenis & 47,2 \\
\hline Mengurus Diri Sendiri & 4,33 \\
\hline Berjalan & 10,05 \\
\hline Mengingat/Berkonsentrasi & 9,4 \\
\hline Berkomunikasi & 10,1 \\
\hline Mendengar & 8,93 \\
\hline Melihat & 9,99 \\
\hline
\end{tabular}

Sumber: BPS, Susenas 2012

Beragamnya jenis ketunaan atau disabilitas ini memberikan perhatian khusus dalam menangani dan melayani kebutuhan hidupnya yang tentu akan berbeda antar jenis disabilitasnya. Akan tetapi, tiap anak dengan disabilitas sama-sama mempunyai hak dalam hal aksesibilitas dan rehabilitas. Mereka membutuhkan akses dan layanan khusus yang diperlukan dalam hidupnya untuk bisa mengatasi berbagai keterbatasannya.

Begitu pula yang dialami oleh anak cerebral palsy. Anak cerebral palsy merupakan bagian dari anak dengan disabilitas yang tergolong pada jenis disabilitas berjalan atau tunadaksa, sebab memiliki gangguan pada pengendalian fungsi pergerakan. Menurut Soeharso (Salim, 2007: 170), bahwa cerebral palsy terdiri dari dua kata, yaitu cerebral yang berasal dari kata cerebrum yang berarti otak dan palsy yang berarti kekakuan. Hal ini dikarenakan adanya gangguan atau kerusakan pada fungsi otak dan sistem saraf, sehingga mengakibatkan 
terjadinya kelainan gerak, sikap, maupun bentuk tubuh, serta gangguan koordinasi pada sistem otot yang menyebabkan kekakuan gerak.

Lebih lanjut disampaikan oleh BakwinBakwin (Somantri, 2006:122) mengenai klasifikasicerebral palsy yang dapat dibedakan sebagai berikut ini:

1. Spasticity, yaitu kerusakan pada cortex cerebri yang menyebabkan hyperactive reflex dan stretch reflex. Spasticity dapat dibedakan menjadi: 1) Paraplegia, 2) Quadriplegia, dan 3) Hemiplegia.

2. Athetosis, yaitu kerusakan pada basal banglia yang mengakibatkan gerakangerakan menjadi tidak terkendali dan tidak terarah.

3. Ataxia, yaitu kerusakan pada cerebellum yang mengakibatkan adanya gangguan pada keseimbangan.

4. Tremor, yaitu kerusakan pada bagian basal ganglia yang berakibat timbulnya getaran-getaran berirama, baik yang bertujuan maupun yang tidak bertujuan.

5. Rigidity, yaitu kerusakan pada basal ganglia yang mengakibatkan kekakuan pada otot-otot.

Berbicara mengenai karakteristik pada anak cerebral palsy, Yulianto (Salim, 2007:178182) mengungkapkan bahwa cerebral palsy mempunyai karakteristik sebagai berikut yaitu mengalami kekakuan-kekakuan otok; terdapat gerakan-gerakan yang tidak terkontrol pada kaki, tangan, lengan, dan otot-otot wajah; hilangnya keseimbangan yang ditandai dengan gerakan yang tidak terorganisasi; otot mengalami kekakuan sehingga seperti robot apabila sedang berjalan; adanya gerakangerakan kecil tanpa disadari; dan anak yang mengalami beberapa kondisi campuran.

Tidak hanya itu, anak cerebral palsy juga dapat disertai dengan gangguan penglihatan, pendengaran, dan mental. Pada kondisi yang demikian, anak cerebral palsy memiliki kemampuan yang terbatas dalam memenuhi kebutuhan hidupnya sendiri. Kesulitan dalam mengontrol gerakan-gerakan kecil, keseimbangan berjalan, dan kesulitan dalam berbicara merupakan beberapa kasus yang menjadi hambatan bagi anak cerebral palsyuntuk bisa aktif dalam berbagai kegiatan sebagaimana yang mampu dilakukan oleh anak-anak pada umumnya.

Mengenai kasus anak cerebral palsy, P. Seibel (1984) memperkirakan jumlah anak-anak cerebral palsy yang berkisar antara 0,15 sampai 0,3 persen dari jumlah populasi anakanak. Dengan demikian setiap 1000 kelahiran hidup, satu sampai tiga anak diperkirakan menderita kelainan cerebral palsy. Sedangkan di Indonesia, 1-5 dari setiap 1000 anak yang lahir hidup di Indonesia memiliki kondisi dengan cerebral palsy. Dengan jumlah angka yang tergolong tidak sedikit ini menunjukkan bagaimana tingkat penyandang cerebral palsy pada anak-anak perlu diperhatikan.

Menyadari hal itu, anak cerebral palsy membutuhkan perhatian khusus dari lingkungan yang mampu mendorong mereka untuk hidup lebih baik lagi. Terutama dalam pemenuhan kebutuhan agar anak mampu menyesuaikan dirinya untuk hidup di tengahtengah lingkungan sosialnya. Mempunyai kesempatan yang sama untuk menjadi mandiri dan berkembang sesuai dengan kemampuan yang dimiliki olehsetiap anak cerebral palsy.

Berbicara mengenai permasalahan tersebut, konsep kesejahteraan sosial dalam gagasannya sebagai suatu sistem pelayanan sosial memandang bagaimana tindakan manusia atau sekelompok manusia yang terorganisasi dapat membantu pemecahan masalah yang dilakukan untuk mencapai tingkat kehidupan masyarakat yang lebih baik. Pelayanan sosial yang dimaksud merupakan salah satu dari usaha kesejahteraan sosial yang dapat diberikan dalam rangka menangani persoalan hidup lewat berbagai layanan pertolongan.

Pada fungsi pelayanan sosial ini, memiliki bentuk-bentuk pelayanan sosial yang di antaranya adalah sebagai berikut: a) Bimbingan sosial bagi keluarga, b) Program asuhan keluarga dan adopsi anak, c) Program 
bimbingan bagi anak nakal dan bebas hukuman, d) Program-program rehabilitasi bagi penderita cacat, e) Program-program bagi lanjut usia, f) Program-program penyembuhan bagi penderita gangguan mental, g) Programprogram bimbingan bagi anak-anak yang mengalami masalah dalam bidang pendidikan, h) Program-program bimbingan bagi para pasien di Rumah Sakit.

Dengan demikian pada fungsi pelayanan sosial ini berfokus pula pada anak dengan disabilitas yang diberikan lewat adanya program-program rehabilitasi sosial sebagai salah satu bentuk pelayanannya.Begitu pun juga halnya dengan anak cerebral palsy yang perlu mendapatkan perlindungan dan rehabilitasi untuk membantu mereka guna menjadikan kehidupannya lebih baik lagi. Dengan berbagai hambatan yang telah disampaikan pada subbab sebelumnya, tentu hal ini mendorong dukungan dari pelayanan sosial yang dapat diberikan bagi anak cerebral palsy dalam mengatasi berbagai hambatan dalam hidupnya. Pelayanan sosial yang diberikan pun termasuk penyelenggaraan pendidikan, akses kesehatan, rehabilitasi, dan juga rekreasi yang dilakukan bagi anak cerebral palsy untuk meningkatkan keberfungsian mereka terutama dalam masa tumbuh dan kembangnya.

Oleh sebab itu, salah satu upaya dalam pelayanan sosial yang dapat menjawab tantangan bagi anak cerebral palsy yakni dengan hadirnya Sekolah Luar Biasa (SLB). Sekolah Luar Biasa sebagai lembaga pendidikan formal yang menyelenggarakan pelayanan sosial yang dibutuhkan bagi anak dalam hal pendidikan dan keterampilan, pengembangan, serta penunjang.

Hal ini mengingat pentingnya penyelenggaraan pendidikan sebagaimana yang dinyatakan dalam Pasal 12 UndangUndang No. 4 Tahun 1997 tentang Penyandang Cacat, bahwa: "Setiap lembaga pendidikan memberikan kesempatan dan perlakuan yang sama kepada penyandang cacat sebagai peserta didik pada satuan, jalur, jenis, dan jenjang pendidikan sesuai dengan jenis dan derajat kecacatan serta kemampuannya."
Adapun tingkat jenjang yang diselenggarakan pada lembaga pendidikan ini, yaitu TKLB, SDLB, SMPLB, dan SMALB. Dengan adanya penyesuaian pada jenis disabilitas atau ketunaan, maka Sekolah Luar Biasa ini diklasifikasikan menjadi enam bagian kekhususan, yaitu SLB bagian A untuk tunanetra, SLB bagian B untuk tunarungu, SLB bagian C untuk tunagrahita, SLB bagian D untuk tunadaksa, SLB bagian E untuk tunalaras, dan SLB bagian G untuk tunaganda.

Pada anak cerebral palsy, selain diselenggarakan layanan pendidikan namun juga disediakan layanan rehabilitasi yang membantu para peserta didik dalam memenuhi kebutuhannya. Dalam satuan sistem pendidikan yang di adakan oleh Sekolah Luar Biasa, diselenggarakan pula pengajaran, latihan, bimbingan, dan rehabilitasi dengan tujuan agar anak cerebral palsy sebagai peserta didik mampu untuk ditunjang dari pertolongan yang dapat diberikan oleh Sekolah Luar Biasa sesuai dengan keadaan diri tiap anak yang berbeda satu dengan yang lainnya.

Penyediaan layanan sosial oleh Sekolah Luar Biasa memberikan kesempatan yang lebih luas lagi pada anak cerebral palsy untuk memenuhi kebutuhannya dalam upaya mencapai keberfungsian sosial mereka. Pelayanan yang diberikan menyesuaikan kondisi penerima layanan dengan berbagai kebutuhan khususnya agar dapat terpenuhi guna membantu mereka untuk memperoleh kehidupan yang lebih baik.

Menyoroti perihal mengenai pemenuhan kebutuhan khususnya maka melihat pula program-program pelayanan sosial yang dijalankan oleh Sekolah Luar Biasa dalam penerapannya bagi anak cerebral palsy, apakah program pelayanan tersebut sudah dijalankan sesuai dengan tujuan yang hendak dicapai atau belum.Sehingga dalam melihat kesesuaiannya, mengacu pada efektivitas yang menunjukkan bagaimana Sekolah Luar Biasa mampu melaksanakan program-programnya guna mencapai tujuan yang telah ditetapkan sebelumnya. 
Untuk dapat mengetahui bagaimana efektivitas dari program atau kegiatan tersebut, Campbell (1989:121) menurutkan bahwa adanya pengukuran efektivitas secara umum, yaitu sebagai berikut: a) Keberhasilan program, b) Keberhasilan sasaran, c) Kepuasan terhadap program, d) Tingkat input dan output, dan e) Pencapaian tujuan menyeluruh. Dengan demikian keefektivitasan itu dapat diketahui berkenaan dengan bagaimana pelaksanaan program yang secara menyeluruh dijalankan agar mencapai sasaran yang dikehendaki.

Konsep pekerjaan sosial yang turut memberikan intervensi kepada anak dengan disabilitas guna meningkatkan keberfungsian sosial anak.Dalam memberikan intervensi tersebut, pekerja sosial dapat melakukan kerangka kerja untuk melakukan analisis, assessment, dan intervensi pada anak dengan disabilitas. Tentunya dalam pemberian intervensi, pekerja sosial akan melibatkan lingkungan sebagai sistem sasaran. Dharta (2011: 75) mengungkapkan bahwa tidak ada satu jenis metode yang secara khusus menjadi suatu intervensi yang efektif bagi semua ABK mengingat hambatan-hambatan dan potensipotensi yang mereka miliki sangat beragam.

Melalui perspektif keadilan sosial, seorang pekerja sosial akan mempromosikan dan mendukung semua orang untuk mendapatkan kesempatan dan kesamaan hak dalam setiap sendi-sendi kehidupan mereka. Peerja sosial juga mengidentifiaksi persoalan-persoalan yang muncul dalam kehdiupan bermasyarakat. Praktik pekerjaan sosial berpotensi memberi pengaruh yang baik bagi kehidupan para ABK. Para pekerja sosial berpraktik dalam komunitas dan setting-setting intervensi yang bervariasi dan secara ideal, mereka berusaha mengidentifikasikan dan mengakomodasikan kebutuhan ABK dan keluarganya. Bekerja secara efektif bersama ABK dan keluarganya menuntut adanya pemahaman mengenai kondisi alamiah $\mathrm{ABK}$ dan bagaimana kondisi itu membawa dampak bagi individu-indiviu dalam keluarga. Kesadaran terhadap nilai-nilai individu dan pengalaman bersama ABK juga akan berpengaruh terhadap sikap dan tindakan seorang pekerja sosial. Penelitian ini dilakukan dengan tujuan untuk mengidentifikasi program pelayanan apa saja yang diberikan pada anak cerebral palsy oleh Sekolah Luar Biasa Yayasan Bhakti Luhur. Kemudian menggambarkan bagaimana efektivitas program pelayanan sosial pada anak cerebral palsy yang diberikan oleh Sekolah Luar Biasa Yayasan Bhakti Luhur dalam penerapannya untuk mengatasi permasalahan yang dihadapi oleh anak cerebral palsy.

\section{HASIL DAN PEMBAHASAN}

Berdasarkan hasil kajian serta penelitian yang telah dilakukan dengan melakukan wawancara kepada informan, baik kepala Sekolah Luar Biasa, guru, pengasuh, dan anak cerebral palsy, serta melakukan observasi partisipasi secara langsung maka dapat diidentifikasi program-program pelayanan sosial yang diberikan sebagai berikut:

\section{Aktivitas Berkebun di Taman}

Salah satu aktivitas yang diselenggarakan oleh Sekolah Luar Biasa Yayasan Bhakti Luhur ini dengan adanya berkebun di taman sekolah. Aktivitas ini dilakukan di setiap pagi oleh seluruh anak cerebral palsy yang dididik. Aktivitas ini bertujuan untuk mengenalkan anak dengan alam. Melalui tumbuh-tumbuhan, anak cerebral palsy belajar mengetahui apa saja macam-macam tumbuhan, bagaimana bentuk, serta merawatnya. Sehingga dengan demikian membantu anak cerebral palsy untuk mampu memahami lingkungan sekitarnya melalui aktivitas berkebun tersebut.

\section{Pembelajaran di Dalam Kelas}

Pembelajaran yang dilakukan di dalam kelas dengan jumlah guru pendamping 1-2 orang. Dalam satu kelasnya, terdiri dari 5-15 anak disabilitas yang dikelompokkan pada masingmasing kemampuan dan tingkat disabilitasnya. Hal ini dilakukan sebagai upaya agar pembelajaran yang diberikan pun menyesuaikan dengan bagaimana keadaan atau kondisi yang dialami oleh tiap anak. 
Begitu pula dengan anak cerebral palsy, terdapat lima anak yang tergolong pada cerebral palsy ringan dan terdapat 6 anak yang tergolong pada cerebral palsy berat. Kedua golongan ini dipisahkan masing-masing, agar guru pendamping dapat menyesuaikan pengajaran yang diberikan kepada tiap-tiap anak.

Pembelajaran terdiri dari rangkaian aktivitas, yaitu menggambar, mewarnai, dan relaksasi. Tidak adanya kurikulum terkait materi akademik yang diberikan secara langsung, sebab pihak yayasan mengatakan bahwa anakanak cerebral palsy ini memiliki keterbatasan sehingga sulit untuk menerima materi akademik jika diberikan. Dengan rangkaian aktivitas di dalam kelas, anak cerebral palsy diajarkan untuk mampu melakukan pengendalian gerakan sensori-motoriknya serta merangsang pola pikir pada kognitifnya agar terjadi keseimbangan dan mampu menangkap apa yang telah diajarkan.

Dengan menggambar dan mewarnai, anak cerebral palsy dikenalkan dengan objek-objek apa yang menjadi tema di hari itu. Sehingga anak mampu mengenal objek yang dipahaminya dari teknik menggambar dan mewarnai sebagai medianya. Dengan relaksasi atau pengulangan kembali, anak cerebral palsy diajak untuk melakukan review dari apa yang telah dipelajari di hari itu. Menguatkan ingatan anak agar

\section{Pemberian Snack}

Selain melakukan pembelajaran, pihak yayasan juga turut memenuhi kebutuhan dasar bagi anak cerebral palsy. Pemberian snack ini dilakukan berdasarkan tema apa yang sedang diangkat oleh yayasan di setiap bulannya. Sehingga, anak terus-menerus dikenalkan dengan objek yang ada dalam kehidupannya. Tidak hanya itu, anak cerebral palsy juga dibimbing oleh pengasuh untuk melakukan kegiatan yang berhubungan dengan snack ini, seperti memasak, menggoreng, dan mencuci alat makan. Anak diajarkan untuk mampu melakukan kegiatan

\section{Fisioterapi dan Sensori Motorik}

Dalam memenuhi kebutuhannya agar anak cerebral palsy dapat hidup lebih mandiri, dibutuhkan pelayanan rehabilitasi yang menyesuaikan kondisi anak cerebral palsy untuk mendapatkan layanan yang membantu memperbaiki gangguan fungsi gerak yang diikuti dengan proses/metode terapi gerak lewat fisioterapi. Tujuan pelayanan ini membantu mengembangkan, memelihara, dan memulihkan fungsi gerak yang terganggu. Dengan berbagai teknik yang telah diterapkan oleh fisioterapis bagi anak cerebral palsy di Sekolah Luar Biasa ini, memberikan kesempatan bagi mereka untuk dapat terlatih pada fungsi geraknya sehingga dengan berbagai proses yang telah dilalui pun membantu anak cerebral palsy agar dapat mampu berjalan dan melakukan gerakangerakan yang menjadikan mereka untuk hidup mandiri.

Selain itu ada pula terapi sensori motorik yang membantu anak cerebral palsy untuk membangun pondasi yang kuat untuk masa depannya. Saat kehidupan semakin rumit dan penuh tuntutan, tanpa adanya penanganan terapi ini maka anak akan mengalami kesulitan dalam keterbatasannya. Penanganan terapi ini membantu anak mengembangkan keterampilan atau keahlian sehingga dapat berinteraksi dengan baik dalam situasi sosialnya. Sehingga bagaimana menjaga anak agar mampu berada di tengah-tengah lingkungan sosialnya, sehingga pemberian layanan terapi sensori motorik yang diterapkan ini menjadikan anak berkembang dalam lingkungan sosialnya. Kegiatan fisioterapi dan sensori motorik ini rutin dilakukan 1-2 kali dalam satu minggu oleh terapis yang professional dalam bidangnya.

\section{SIMPULAN DAN SARAN}

Berdasarkan hasil penelitian yang telah dilakukan sebelumnya, maka dapat disimpulkan bahwa kondisi anak cerebral palsy dengan berbagai kebutuhan khususnya perlu diperhatikan guna keberlangsungan hidupnya. Bagaimana mereka berada dalam 
keterbatasan-keterbatasan yang seharusnya dapat dibantu lewat intervensi pelayanan sosial yang diberikan sebagai usaha untuk mengatasi berbagai keterbatasannya tersebut.

Sekolah Luar Biasa Yayasan Bhakti Luhur telah memberikan berbagai program pelayanan sosial pada anak cerebral palsy untuk keberlangsungan hidupnya dan menjadikan mereka anak yang terampil dan mandiri. Akan tetapi, kurangnya tenaga pengajar dan sumber daya manusia terkait dengan pembimbingan anak cerebral palsy sehingga program pelayanan sosial seperti pembelajaran di dalam kelas belum efektif dilakukan oleh sekolah. Sedangkan untuk program rehabilitasi, pemberian snack, dan berkebun sudah dilakukan secara efektif oleh sekolah, sehingga anak cerebral palsy mampu memahami apa yang diajarkan dan meminimalisir keterbatasan mereka dalam segi mobilitas lewat adanya fisioterapi dan sensori motorik. Pemenuhan kebutuhan lewat berbagai program pelayanan sosial ini membantu anak untuk berkembang dalam hidupnya dan tentu dengan penyesuaian kondisi yang dialami oleh tiaptiap anak cerebral palsy yang dididik.

Adapun saran atau rekomendasi yang dapat diberikan oleh peneliti, yaitu:

1. Perlunya penambahan tenaga pendidik dan sumber daya manusia yang terkait dengan pembimbingan anak cerebral palsy agar dapat membantu mereka untuk meningkatkan kemampuan diri dalam berkembang dan mandiri.

2. Pemberian pelayanan sosial hendaknya mengacu pada kebutuhan anak cerebral palsy yang berbeda-beda, agar hasilnya lebih optimal. Penyesuaian kondisi ini membantu anak agar mendapatkan layanan yang benar-benar sesuai dengan kebutuhan apa yang mampu mengatasi keterbatasannya tersebut.

3. Perlunya perluasan materi pembelajaran dan penerapan kurikulum yang dapat membantu anak cerebral palsy agar lebih luas lagi menerima pembelajaran akademik yang tentunya disesuaikan kembali dengan kondisi tiap-tiap anak cerebral palsy.

$$
* * * * *
$$

\section{DAFTAR PUSTAKA}

Burhan, Bungin. 2007. Penelitian Kualitatif: Komunikasi, Ekonomi, Kebijakan Publik, dan Ilmu Sosial Lainnya. Jakarta: Prenada Media Group.

Campbell. 1989. Riset dalam Efektivitas Organisasi Terjemahan Sahat Simamora. Jakarta: Erlangga.

Creswell, John W. 2003. Research Design Qualitative, Quantitative, and Mixed Methods Approaches. London: Sage Publications, Inc.

Creswell, John W. 2007. Qualitative Inquiry \& Research Design. London: Sage Publications, Inc.

R, Gold, Seibel P, Reinelt G, et al. 1996. Phosphorous Magnetic Resonance Spectroscopy in The Evaluation of Mitochondrial Myopathies: Results of A 6 Month Therapy Study With Coenzyme Q.

Salim, Abdul. 2007. Pediatri dalam Pendidikan Luar Biasa. Jakarta: Departemen Pendidikan Nasional Direktorat Jenderal Pendidikan Tinggi Direktorat.

Somantri, Sutjihati. 2006. Psikologi Anak Luar Biasa. Bandung: Refika Aditama.

Sugiyono. 2014. Metode Penelitian Kuanitatif, Kualitatif, dan R\&D. Bandung: Alfabeta. 